DIANA SORIĆ

UDC: 821.124 .09

TEUTA SERREQI JURIĆ

University of Zadar

Croatia

\title{
LITERARY ASPECTS OF ANTUN VRANČIĆ'S TRAVELOGUE ITER BUDA HADRIANOPOLIM
}

\begin{abstract}
Iter Buda Hadrianopolim is a travelogue written by the Croatian humanist Antun Vrančić (1504-1573), in which the author describes his diplomatic journey that took place in 1553. Although his final destination was Constantinople, the travelogue has been preserved fragmentarily, covering the section from Buda to present day Turkish city of Edirne. During his journey, Vrančić had the opportunity to see a large number of cities, forts, villages, rivers and mountains. Numerous digressions and descriptions, especially of the customs of people, and interpretations of toponyms, hydronyms and oronyms make this travelogue very interesting. The aim of this paper is to review Iter Buda Hadrianopolim as a literary work, and to show that although it lacks the description of the last leg of the journey for unknown reasons, this travelogue contains most of the key elements of the travelogue literary genre (the narrator who states the time and place of the journey, a specified reason for the journey and the person who commissioned it, a specific itinerary, digressions, educational elements, narrative and descriptive passages), so it can undoubtedly be counted as a real, non-fictional travelogue.
\end{abstract}

Keywords. - Antun Vrančić, humanism, travelogue, toponyms, Ferdinand I

\section{The facts behind the travelogue and the purpose of the paper $^{1}$}

Even though letters form a major part of the literary corpus of the Croatian humanist, cleric, statesman and diplomat Antun Vrančić (1504$1573),{ }^{2}$ literary tradition has also preserved the travelogue Iter Buda

${ }^{1}$ This paper was presented in its shortened form at the 17th International Congress of the International Association for Neo-Latin Studies (IANLS): "Humanity and Nature: Arts and Sciences in Neo-Latin Literature”, Albacete (Spain), 29 July - 3 August 2018.

${ }^{2}$ Antun Vrančić was born in Šibenik on May 30, 1504. He descended from a distinguished noble family, and was brought up with the help of his two noble relatives, kinsman Petar Berislavić (cca. 1450-1520), a Bishop of the Hungarian town of Veszprém and Ban of Croatia from 1513 to 1520, and uncle Ivan Statilić (cca. 1472-1533), a Bishop of the town of Erdély and a diplomat at the court of King Louis II Jagiellon (1506-1526) and King John Zápolya (1487-1540). Vrančić's political career started when he entered the service of John Zápolya, becoming his royal secretary in 1530 thanks to his uncle Ivan Statilić, who sided with Zápolya during the struggle over the 
Hadrianopolim under his name as an account of his first diplomatic mission to Constantinople from 1553 to $1557 .{ }^{3}$ After Vrančić joined the service of Ferdinand I Habsburg, he gradually gained his trust, so Ferdinand began appointing him to numerous diplomatic missions, among which the most demanding was Vrančić's aforementioned mission. Habsburg emissaries were sent to the Turkish Sultan Suleiman with the purpose of securing Habsburg-Ottoman peace, solving their dispute over Transylvania, as well as resolving the issue of a long imprisonment of ambassador Malvezzi. ${ }^{4}$

This travelogue does not contain the description of a complete journey to Constantinople. Its timeline begins on 25 July 1553, the day when the delegation set out from Buda via the Danube, and ends with its arrival in Turkish city of Edirne (Latin Hadrianopolis) on 19 August of the same year. The emissaries travelled by river boats along the Danube, the Morava, the Nišava and the Maritsa, and by carriage and horses on land. On this relatively long journey, Vrančić had the opportunity to see quite a few cities, forts, villages, rivers and mountains, whose names and location he had read about in the works by the famous ancient geographers Ptolemy and Strabo. ${ }^{5}$ Thus, by consulting

Hungarian throne. After Vrančić decided to leave the Transylvanian court, in 1549 he joined the service of Ferdinand I Habsburg and quickly became his secretary. He attained the highest honor at the Habsburg court in 1572, when he became the Regent of Hungary. Besides this, Vrančić was appointed to a number of senior ecclesiastical positions he was the Bishop of the Hungarian towns of Pécs and Eger, the Archbishop of Esztergom, a city in Northern Hungary, and finally, the Primas of Hungary, ie. the chief of the Catholic Church in Hungary. Vrančić died on June 15, 1573, in the town of Prešov which at the time was in Northern Hungary. More on the life of Antun Vrančić and on his literary output see: Darko Novaković, Vladimir Vratović, S visina sve. Antun Vrančić (Zagreb: Globus, 1979); Marianna Daisy Birnbaum, Croatian and Hungarian Latinity in the Sixteenth Century (Zagreb: Most, 1993); Darko Novaković, Sentimentalni odgoj. Antun i Faust Vrančić (Šibenik: Gradska knjižnica "Juraj Šižgorić", 1995), 5-23; Diana Sorić, "Klasifikacija pisama Antuna Vrančića", Colloquia Maruliana XVIII (2009), 83-117; Diana Sorić, "Obiteljska korespondencija Antuna Vrančića: kritičko izdanje rukopisa i jezičnostilske osobitosti" (doktorska disertacija, Sveučilište u Zadru, 2012), 7-24; Diana Sorić, "Obiteljski korespondenti Antuna Vrančića (1504.-1573.): Biografski podaci i lokacija rukopisne građe”, Povijesni prilozi 47 (2014), 35-61; Antun Vrančić, Historiografski fragmenti., eds. Šime Demo and Castilia Manea-Grgin (Šibenik: Gradska knjižnica "Juraj Šižgorić", 2014), 7-70; Diana Sorić, "Pitanje datuma rođenja hrvatskog humanista i ugarskog primasa Antuna Vrančića (1504.-1573.)", Croatica Christiana periodica 39 (2015), br. 75: 37-48; Zrinka Blažević, Anđelko Vlašić, eds., Carigradska pisma Antuna Vrančića (Istanbul: Hrvatska akademija znanosti i umjetnosti, 2018), 28-63.

${ }^{3}$ Apart from his travelogue, Vrančić also wrote a short text on the journey in the form of a dialogue with his brother Mihovil. The autograph of the dialogue is kept in the National Széchényi Library in Budapest, under the call number 2380 Fol. Lat. III, ff. $58-80 \mathrm{v}$.

${ }^{4}$ More on this mission in: Petar Matković, "Putovanja po balkanskom poluotoku XVI. vieka. Putovanje A. Vrančića g. 1553. u Carigrad", Rad JAZU 71 (1884), 2-4; Novaković, Vratović, S visina sve, 117-151; Blažević, Vlašić, Carigradska pisma, 35-55.

${ }^{5}$ Vrančić most likely used some contemporary Latin translations of Ptolemy and Strabo, which are unknown to us for the time being (Matković, "Putovanja po balkanskom 
this literature, which he often mentions in his travelogue, on the one side, and by travelling through these regions and directly familiarizing himself with them on the other, our traveller records a large number of names of places, rivers and mountains. Vrančić, a responsible travel writer, also described important landmarks of the places he saw, which means that his text certainly does meet the criteria for a travelogue.

The purpose of our paper is to evaluate Vrančić's travelogue in the context of this literary genre and to show how much its author adhered to the conventions of the travel discourse. Additionally, we will point out the many interesting features which this literary text has to offer to the reader, including the facts about Vrančić's erroneous interpretations of various place and river names, which is in no way intended to diminish the value of his explanations, but to present these mistakes as a curiosity.

\section{The handwritten tradition and the editions of Vrančić's travelogue}

The following is known about the handwritten tradition of this text by Vrančić: the autograph of the travelogue is kept in the National Széchényi Library in Budapest, under the call number $2380 \mathrm{fol}$. Lat. III, ff. 81-112v and 422 fol. Lat. II, ff. 77-98v.

Furthermore, a transcript of Vrančić's travelogue can be found within the second book of the manuscript De Illyrico Caesaribusque Illyricis by the Croatian humanist Ivan Tomko Mrnavić (1580-1637). There are three copies of this transcript: one copy is kept at the National and University Library in Zagreb under the call number R7195 (pp. 118-151), another in the National Museum of Bosnia and Herzegovina in Sarajevo under the call number E541 (ff. 76v-92) and the third in the Monastery Mala braća in Dubrovnik (ff. 23v-29).

As far as the editions of this document are concerned, the earliest is the one by the Italian travel writer Alberto Fortis from 1774, who included Vrančić's travelogue in his own Viaggio in Dalmazia. ${ }^{7}$ The whole travelogue was for the second time published in 1857, in the famous Hungarian edition of Monumenta Hungariae Historica II/2 by László

poluotoku", 15). In addition to the two geographers Vrančić most frequently relies on and refers to, at the very end of his travelogue he mentions two other writers he used as sources - the Roman geographers Gaius Julius Solinus ( $3^{\text {rd }}$ century A.D.) and Pomponius Mela ( $1^{\text {st }}$ century A.D.).

6 Tamara Tvrtković, "Marko Marulić u djelu Ivana Tomka Mrnavića", Colloquia Maruliana XVI (2007), 295-297. We express our gratitude to Tamara Tvrtković, PhD for the use of the transcripts.

${ }^{7}$ Alberto Fortis, Viaggio in Dalmazia (Venezia: Presso Alvise Milocco, 1774), 215 261. In the Croatian translation of Fortis's book, a translation of Vrančić's travelogue Iter Buda Hadrianopolim by Darko Novaković can be found (Antun Vrančić, Putovanje iz Budima u Drinopolje, in: Alberto Fortis, Put po Dalmaciji, ed. Josip Bratulić, transl. Mate Maras and Darko Novaković (Zagreb: Globus, 1984), 115-145). 
Szalay. ${ }^{8}$ A minor part of the travelogue can also be found in the book Historia episcopatus Quinqueecclesiensis, tomus V by József Koller. ${ }^{9}$
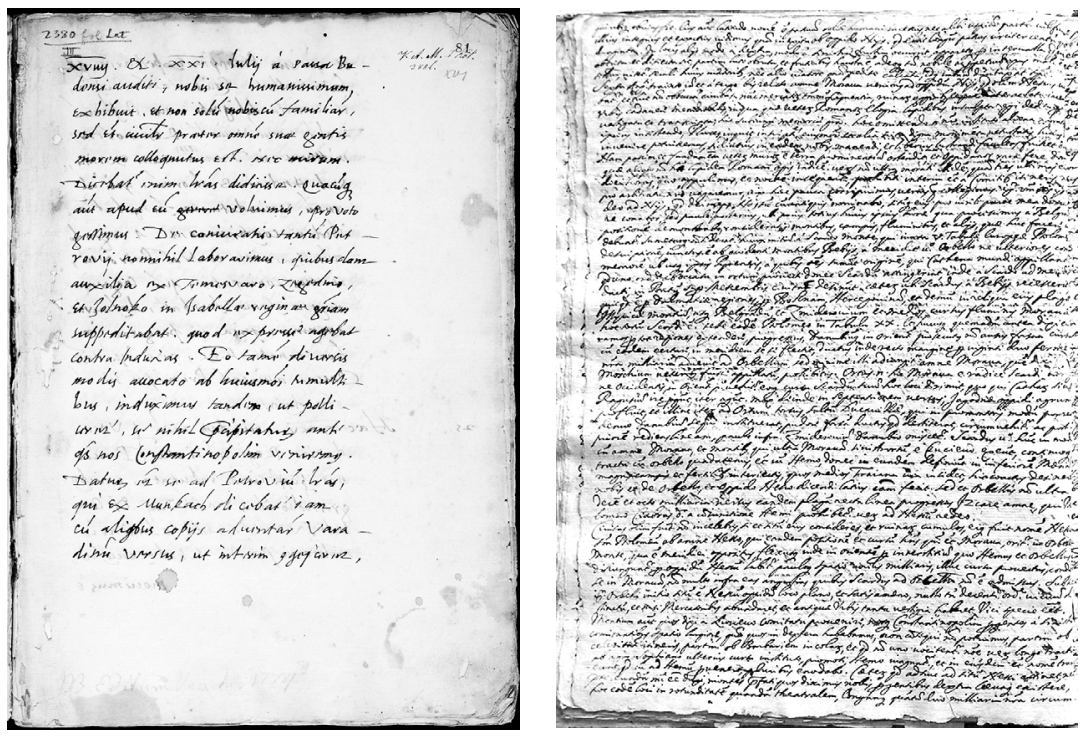

Vrančić's autograph from Budapest: 81; manuscript from Dubrovnik: 25v
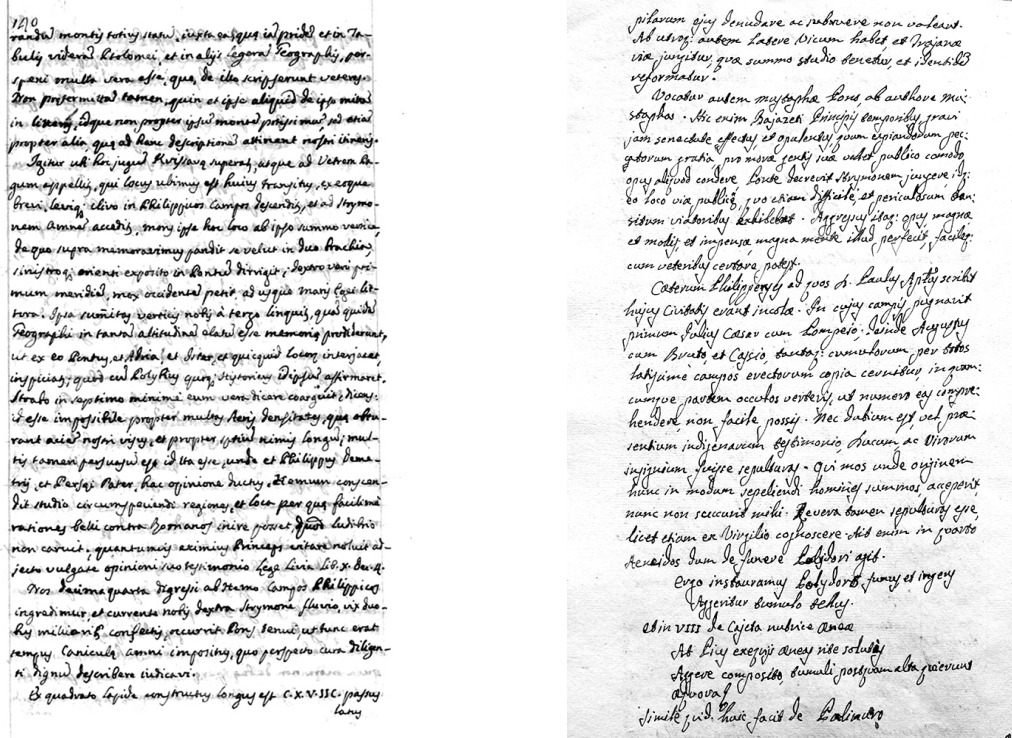

Examples of manuscripts from Zagreb and Sarajevo: $Z g$ 140; $S a$ 89v

${ }^{8}$ L. Szalay, Monumenta Hungariae Historica II/2 (Pest, 1857), 288-334.

9 Jószef Koller, Historia episcopatus Quinqueecclesiensis, V (Posonii et Pestini: Sumptibus Joannis Michaelis Landerer, 1782-1784), 335-336. 


\section{Literary elements of Vrančić's travelogue}

In his book Priča i putovanje, Dean Duda defines a travelogue as a text about a credible journey taken by the narrator (traveller, observer, travel writer) who recounts his or her adventures on the road, describes the places he or she travels through and stays in, makes observations about the people he or she encounters, about their customs and way of life, and the culture and art of the places he or she visits. ${ }^{10}$ The main modes of discourse used by the travel writer are narration and description, and the main elements are:

- the narrator who states the time and place of the journey sioned it

- a specified reason for the journey and the person who commis-

- a specific itinerary

- a lexicon (catalogue)

- digressions as supplementary thematization

- educational elements

- narrative and descriptive passages. ${ }^{11}$

Below we shall list the elements of the travel discourse which can be found in Vrančić's text.

\subsection{The narrator}

The narrator is already known - it is the humanist Antun Vrančić, who states the time and place of the journey recounted in the travelogue, as an emissary of Emperor Ferdinand I.

\subsection{A specified reason for the journey, the person who commissioned it and a specific itinerary}

The reason for the journey and the person who commissioned it, i.e. Ferdinand I, are determined by the fact that it was a diplomatic mission initiated by the sovereign of the Croatia-Hungary Kingdom, with the clear aim of concluding a treaty with Turkey, namely Suleiman. The itinerary is determined with Buda as the place from where Vrančić set off and Constantinople as his final destination.

\subsection{Narration and descriptions}

Narration and descriptions are the travel writer's basic modes of discourse. The narration covers events that happen on the road (adventures of the travel writer/narrator), and descriptions cover the subject matter of the world of travel (people, places, buildings, works of art,

\footnotetext{
${ }^{10}$ Dean Duda, Priča i putovanje. Hrvatski romantičarski putopis kao pripovjedni žanr (Zagreb: Matica hrvatska, 1998), 48.

${ }^{11}$ Duda, Priča i putovanje, 92.
} 
etc.). ${ }^{12}$ In accordance with the conventions of the travelogue, narrative and descriptive passages alternate in Vrančić's book also. The narrative passages are present owing to the very act of travelling through certain lands, which makes the basis of the events that Vrančić recounts, and he does this according to the chronology of the journey itself. On the other hand, the most common mode of discourse used by our travel writer to portray and present the reality he encounters is description. Below are some interesting examples.

Vrančić often takes the opportunity to describe landscapes and towns, and he especially focuses on detailed descriptions of the architecture of the towns and villages he visits. Such an example can be found in the chapter where Vrančić describes the bridge on the River Topolnica in Bulgaria:

"Nos XIIII. Augusti digressi ab Hemo campos Philippicos ingredimur, et currente nobis dextra Strymone fluuio, uix duobus milliaribus confectis, occurrit pons tenui, ut tunc erat tempus caniculae, amni impositus, quo perspecto cura diligenti dignum descriptione iudicaui.

Ex quadrato lapide constructus, longus est CXVIII passus, latus minus IX. Quinque habet fornices, medias III magnas et altas, extremas utroque in cornu mediocres ac humiles, sed maiorum duae collapsae trabibus erant reparatae, et quacunque fuit integer, communi lapide stratus est, habetque a lateribus ex quadratis lapidibus ad umbilicum hominis erecta latera, quae a casu tutantur transeuntes, dum conferti concursu inter sese stiparentur, et praeterea ut esset locus initendi iis, qui amnem ceteraque subiecta circum oculis prospectarent. In eo nulla visitur inscriptio. Ceterum opus Turcicum est. Fluuius cui est impositus Topolniza uocatur, fluitque ex his Hemi montibus, quos a sinistra in Pontum directos esse dixeram, moxque a ponte vix duobus millibus passuum lapsus condit sese in Strymonem." 13

Our travel writer also established himself as a virtuoso in describing people, when he mentions Bulgarian women he saw in the village of Suha Klisura. This prozopographic digression covers almost two pages, where Vrančić put a lot of effort into very detailed descriptions of their hairstyles, jewellery, and clothing, that is to say their overall appearance. Here is just one segment of description regarding their hairstyle:

"Crines a fronte discriminali facto in tenues et crebras tricas colligunt, ductoque earundem tricarum sic ordine collectarum margine

12 Duda, Priča i putovanje, 48.

${ }^{13}$ All Latin quotes have been taken from the autograph of Vrančić's Iter Buda Hadrianopolim kept in the National Széchényi Library in Budapest. Hungary (further: HU) - Országos Széchényi Könyvtár, Budapest (further: OSZK) - 422 - fol. Lat., II, ff. $84 \mathrm{v}-85 \mathrm{v}$. 
per tempora et supra aures, additaque etiam illis ex staminum laneorum in crinium colorem tinctorum quaedam quasi supplementa eisdem adhibent, ut appareant copiosiores; reiiciunt in tergus et in unum quoddam velut rete astringunt, et demitunt infra cingulum. Hoc virgines." 14

Vrančić also often describes examples of Turkish ruthlessness and cruelty which can be seen everywhere. For example, when the delegation came to Sremska Kamenica in Serbia, Vrančić first relates what the town once looked like, and then describes what he sees:

"Centum quinquaginta domos lapideas extructas et decenti ordine positas, ne luteas easque numerosas reliquae plebis casas enumerem, in eo videre erat. Nunc omnino vix cernuntur XV stramineae." 15

As a typical example of a description of the reality at the time, the following commentary by the author can be given, provoked by his encounter with passing slaves driven by the Turks:

"Hoc pergentes tractu Turcas quosdam assequimur, qui equos ac mulos plenis hominum corbibus pellebant oneratos, parsque eorum, qui gestabantur in hunc modum, persona linei panni habebant tectas facies, pars vero apertas. Quae res etiam mihi praebuit causam quaestionis. Nouitas enim eiusmodi, in solo tam a nostro alieno, monstri cuiuspiam fecerat speciem." 16

From this quote some characteristics of the author can be inferred. The verb which we find in the last sentence, "to inquire", together with the phrases "territory so foreign to ours" and "a monstrous sight" tell us at least two things about the narrator. Vrančić is not a traveller who only observes the lands and people he encounters, but rather his role becomes active, coloured by his desire for new knowledge, which he can obtain only through communication, that is to say, by inquiring with the domestic population or a chance passer-by, who then takes the role of a mediator or an assistant in the transfer of information.

When the narrator of a travelogue visits a foreign country, which for him or her is full of unusual, miraculous and new things, he or she usually compares it to his or her own country. Vrančić is also a traveller who likes to compare countries; however, he does not compare the foreign lands to his hometown of Šibenik. As he had lived and worked for many years in present-day Transylvania (Erdelj at the time), it is only to be expected that he would make comparisons with this land. Thus, in several places in the travelogue, the author highlights the differences or similarities between the lands he travels through the land he comes from. There are few examples of such comparisons:

14 Hungary (further: HU) - Országos Széchényi Könyvtár, Budapest (further: OSZK) - 2380 - fol. Lat., III, ff. 108v-109.

${ }^{15} \mathrm{HU}-\mathrm{OSZK}-2380-$ fol. Lat., III, f. 86v.

${ }^{16} \mathrm{HU}-\mathrm{OSZK}-2380-$ fol. Lat., III, ff. 97-97v. 
"Eius autem vrbis forma ${ }^{17}$ triquetra est, longior quam latior, altis moenibus ac XXX circiter turribus rectis, quadratis, equalibus et dimidiatim foras prominentibus, interiore in vetustum morem patentibus, opertis, tabulatorumque serie distinctis, magnitudine mediocri, Sopronio tamen nostro paulo amplior."18

"Domus in ipsa nulla est insignis, nulla ferme lapidea; omnes humiles et humo tenus tectę et ligneę. Et si quae sunt nobiliore structura, ex formato quidem latere factae sunt, sed incocto et cuppis tantum coctilibus opertae. Templis dumtaxat ornata est Turcicis et eminentibus eorum columnis cocleis, quae in campanilium nostrorum morem euectae eminentius praebent speciem vrbibus non indecorem."19

“... et Izcarem vocant, ut iam diximus. Ceterum flumen Chrysio nostro Transsylvano, quem a Sebeso Sebesianum appellant Chrysium, pari est magnitudine, sed nisi interventu imbrium ac resolutione niuium. $" 20$

\subsection{Digressions as supplementary thematization}

What makes this book very interesting is the author's tendency to insert stories about certain towns or places that he had either known about before or learned on the journey itself. Such an example of supplementary thematization, ${ }^{21}$ which implies an addition to the basic theme, can be found at the very beginning of the travelogue when Vrančić hears a strange story about Harsan mountain from his companion and colleague Ferenc Zay:

"Esse in eius cacumine pervetustam et iam desolatam arcem, in eaque puteum superesse profundum et cauernosum, in quem quicquid deieceris, quod natura aquis libratur nec in ima demergitur, effluere in Drauum, qui ei in quinto nostro subsit milliario a septentrionibus. Res autem in anate dicitur aliquando praebuisse experimentum, quae proiecta cum signo alligato in memoratum puteum, paucis diebus post visa est cum eodem signo nare per Drauum.."22

Vrančić also builds on the story of the town of Ilok with practically a succession of digressions serving as supplementary thematization. While mentioning the town of Ilok, which was once known for paying a lot of money to Duke Lovro of Ilok, the author tells the story about a very unpopular tax, the so-called "coin tax", according to which

\footnotetext{
${ }^{17}$ Smederevo in Serbia.

${ }^{18}$ HU-OSZK-2380-fol. Lat., III, f. 93.

${ }^{19}$ HU-OSZK-2380-fol. Lat., III, ff. 111v-112.

${ }^{20}$ HU-OSZK-422-fol. Lat., II, f. 78.

${ }^{21}$ More on the term in Duda, Priča i putovanje, 134.

${ }^{22}$ HU-OSZK-2380-fol. Lat., III, f. 84.
} 
the subjects were obliged to pay their duke one coin. To this story he adds a new story about the humorous witticisms of four Hungarian magnates. The succession could be presented as follows: the town of Ilok $\rightarrow$ "coin tax" $\rightarrow$ the story of the funny witticisms of the four Hungarian magnates. ${ }^{23}$

"Atthiae proxima Vylacchum est, quam Rasciani Illok vocant, multum olim memorabilis ac ne nunc quoque obscura, curaque diligenti custoditur a Turcis. Erat autem olim ducis Laurencii et eius cognomine utebatur, quod habebat hereditariam. Habuit Vylacchum proventus maximos. Caeterum unum ultimę conditionis habitum non praetermittam referre, qui appellatus est obolarius ab unius oboli collatione. Nec succurrit quibus ex rebus proveniebat; eius tamen summa pecuniae ascendebat ad VI millia aureorum, feruntque eam pensionem supra quam dici possit molestam et onerosam semper fuisse subditis. Quare sepenumero XX millia aureorum duci suo quotannis pendere voluerunt, si eo proventu eos liberasset. Exorari tamen nunquam potuit et professus est, si centupplum pendissent, se non facturum, ne eius institutores iniuria afficeret. Vnde quattuor primariorum regulorum Hungariae, Thomae Strigoniensis archiepiscopi, Stephani Bathorei, N. Orzägi et Laurencii ducis IIII facete dicta memorantur. Primis tribus tria erant oppida. Priori Kemencze, quod fornacem significat, proximo Karon, quod damnum, tercio Giengies, quod vniones, quarto hic prouentus obolaris, quem Fyller uocant. Quum igitur III illi a Strigoniensi archiepiscopo conviuio fuissent aliquando excepti, mutuoque inter sese de magnitudine opum familiariter concertarent, Stephanus forte Bathoreus prior per extenuationem damnosi nominis tantas sibi opes esse diceret, vt ex damno etiam redditus illi maximi provenirent. Subiunxit N. Orzagus suas vero tantas, ut canes etiam apud eum in vnionibus ambularent. Laurentius dux protulit obolarem redditum. Thomas demum, quia e re nata hic sermo in medium prodierat, cupiens ipse etiam aliquid afferre simile, subita cogitatione ditionem suam percurrit ac inquit: 'Domini, mihi quoque fornax est, aut malitis stuba ea amplitudine, ut aliquot millibus hominum hospitia suppeditare possit." 24

Another example of supplementary thematization is the story of the Serbian war hero Pavle Bakić, ${ }^{25}$ which Vrančić inserts after the description of the village of Livada, where Pavle's house was located:

${ }^{23}$ In addition to the already mentioned Lovro of Ilok, this section is about Toma Bakač (1442-1521, Archbishop of Ostrogon from 1497), the Hungarian magnate and a follower of Ferdinand I. István Báthory $(+1530)$ and, most probably, Mihály Ország, who was the Palatine of Hungary from 1458 to 1484 (according to D. Novaković in Vrančić, Putovanje iz Budima, 122, note 6).

${ }^{24}$ HU-OSZK-2380-fol. Lat., III, ff. 84v-86r.

${ }^{25}$ Pavle Bakić (†1537) was the last to hold of the title of Serbian despot in Hungary. At the end of 1525 he fled to Hungary and participated with his soldiers in the Battle 
"Eodem die Liuadam pagum venimus, qui est ad torrentem Ieszenizam et syluam Lomnizam situm. Quem locum dum peragramus et inambulamus aduerso torrente, didicimus domum Pauli Bakyth Venciaz nominatam haud longe fuisse, in qua olim, antequam a Turcis ad nos transiret, habitabat. Qui Paulus homo erat, ut scis, e Rascianis oriundus, et quum ob virtutes bellicas, quibus insigniter pollebat, tum ob fidem in regem nostrum non uulgarem, dignus certe est, ut eius viuat memoria. Vt enim non obscure vixit, meritoque inter ductores belli relatus fuerat, ita etiam obiit clara et memorabili morte, clade Ioannis Coceaneri ${ }^{26}$ in comitatu Valco apud arcem Ivancam (quae erat, antequam a Turcis capta est, Francisci Zay collegę mei), dum fugientis nostri exercitus qua frontem, qua latera, et demum omnes partes vnus inter duces, magno animo et periculo suo protegendo, identidem in hostium insultantium procurrit cuneos. ${ }^{27}$

\subsection{Lexicon (Catalogue)}

An integral part of a travelogue is also a lexicon or a catalogue relating to the process of structuring the information about the geographic and cultural area covered by the travelogue. Vrančić recorded a large number of place names (toponyms), which can be divided into the ones related to towns (oppidum/urbs), fortresses (arx), forts (castellum), villages (vicus/pagus) and districts (comitatus). ${ }^{28}$

\begin{tabular}{|l|l|l|l|l|}
\hline \multicolumn{1}{|c|}{ Oppidum } & \multicolumn{1}{|c|}{ Arx } & Castellum & \multicolumn{1}{|c|}{ Pagus/ Vicus } & Comitatus \\
\hline $\begin{array}{l}\text { Sicambria } \text { (Old } \\
\text { Buda, Hungary) }\end{array}$ & $\begin{array}{l}\text { Kewzeg (possibly } \\
\text { the destroyed cas- } \\
\text { trum Kuzegh } \text { near } \\
\text { Batina, Croatian- } \\
\text { Serbian border) }\end{array}$ & $\begin{array}{l}\text { Baian } \\
\text { (Hungary) }\end{array}$ & $\begin{array}{l}\text { Zeremlenium } \\
\text { (Hungary) }\end{array}$ & $\begin{array}{l}\text { Branicieuo } \\
\text { (Braničevo } \\
\text { Serbia) }\end{array}$ \\
\hline
\end{tabular}

of Mohács against the Ottomans in 1526. In the conflict over the Hungarian throne he sided with John Zápolya. After Zápolya's defeat, Bakić sided with Emperor Ferdinand I (1503-1564), who appointed him a Despot in 1537. He died the same year in the battle against the Ottomans near Đakovo.

${ }^{26}$ John Katzianer (1491/1492-1539), the chief commander of the army of Emperor Ferdinand I, defeated John Zápolya in the battles near Tokaj (1527) and Košice (1528).

${ }^{27}$ HU-OSZK-2380-fol. Lat., III, ff. 96v-97.

28 The catalogue contains a list of places that were part of Vrančić's scheduled itinerary from Buda to Edirne. Accordingly, the places mentioned in his digressions are not mentioned here.

${ }^{29}$ The names of places are listed according to Vrančić's autograph and in the order in which they appear in the text. For the identified toponyms, their current names and the country in which they are located are also given (according to Johan G. T. Grässe et al., Orbis Latinus. Lexikon lateinischer geographischer Namen des Mittelalters und der Neuzeit (Braunschweig: Klinkhardt \& Biermann, 1972) and according to the translation by D. Novaković (see note 6)). 


\begin{tabular}{|c|c|c|c|c|}
\hline Oppidum & Arx & Castellum & Pagus/Vicus & Comitatus \\
\hline $\begin{array}{l}\text { Buda (Buda, } \\
\text { Hungary) }\end{array}$ & $\begin{array}{l}\text { Erdewd (Erdut, } \\
\text { Croatia) }\end{array}$ & $\begin{array}{l}\text { Corosca } \\
\text { (Serbia) }\end{array}$ & $\begin{array}{l}\text { Grocka (Grocka, } \\
\text { Serbia) }\end{array}$ & $\begin{array}{l}\text { Cuciaeuo } \\
\text { (Kučevo, } \\
\text { Serbia) }\end{array}$ \\
\hline $\begin{array}{l}\text { Pestum (Pest, } \\
\text { Hungary) }\end{array}$ & $\begin{array}{l}\text { Boroh (Borovo } \\
\text { Naselje, Croatia) }\end{array}$ & & $\begin{array}{l}\text { Livada (Livada, } \\
\text { Serbia) }\end{array}$ & \\
\hline $\begin{array}{l}\text { Räzkevi (Rázkeve, } \\
\text { Hungary) }\end{array}$ & $\begin{array}{l}\text { Valco (Vukovar, } \\
\text { Croatia) }\end{array}$ & & $\begin{array}{l}\text { Rasgni (Ražanj, } \\
\text { Serbia) }\end{array}$ & \\
\hline $\begin{array}{l}\text { Pacchos (Paks, } \\
\text { Hungary) }\end{array}$ & $\begin{array}{l}\text { Zatha (Sotin, } \\
\text { Croatia) }\end{array}$ & & $\begin{array}{l}\text { Zuha Clyszura } \\
\text { (Klisura, Bulga- } \\
\text { ria) }\end{array}$ & \\
\hline $\begin{array}{l}\text { Tolna (Tolna, } \\
\text { Hungary) }\end{array}$ & $\begin{array}{l}\text { Atthya (Šarengrad, } \\
\text { Croatia) }\end{array}$ & & $\begin{array}{l}\text { Czarew Brod } \\
\text { (Carev Brod, } \\
\text { Bulgaria) }\end{array}$ & \\
\hline $\begin{array}{l}\text { Batha (Báta, } \\
\text { Hungary) }\end{array}$ & $\begin{array}{l}\text { Vylacchum (Ilok, } \\
\text { Croatia) }\end{array}$ & & $\begin{array}{l}\text { Belliza (Belitsa, } \\
\text { Bulgaria) }\end{array}$ & \\
\hline $\begin{array}{l}\text { Mohacium (Mo- } \\
\text { hách, Hungary) }\end{array}$ & $\begin{array}{l}\text { Banmonostra } \\
\text { (Banoštor, Serbia) }\end{array}$ & & $\begin{array}{l}\text { Tarnaw (Trnovo, } \\
\text { Bulgaria) }\end{array}$ & \\
\hline $\begin{array}{l}\text { Veresmarth (Hun- } \\
\text { gary) }\end{array}$ & $\begin{array}{l}\text { Cierewgy (Čere- } \\
\text { vić, Serbia) }\end{array}$ & & $\begin{array}{l}\text { Vaccharel (Va- } \\
\text { karel, Bulgaria) }\end{array}$ & \\
\hline Lazkò (Hungary) & $\begin{array}{l}\text { Varadinum Petri } \\
\text { (Petrovaradin, } \\
\text { Serbia) }\end{array}$ & & $\begin{array}{l}\text { Vetren (Vetren, } \\
\text { Bulgaria) }\end{array}$ & \\
\hline Pathay (Hungary) & $\begin{array}{l}\text { Zalonkemen (Slan- } \\
\text { kamen, Serbia) }\end{array}$ & & $\begin{array}{l}\text { Gouedar (Gove- } \\
\text { dare, Bulgaria) }\end{array}$ & \\
\hline $\begin{array}{l}\text { Kemencze/Ka- } \\
\text { mencz/Kamonz } \\
\text { (Sremska Kame- } \\
\text { nica, Serbia) }\end{array}$ & $\begin{array}{l}\text { Titulium (Titel, } \\
\text { Serbia) }\end{array}$ & & $\begin{array}{l}\text { Cognuus/Con- } \\
\text { sthyza (Konji } \\
\text { /Konjštice, Bul- } \\
\text { garia) }\end{array}$ & \\
\hline $\begin{array}{l}\text { Karon (Sremski } \\
\text { Karlovci, Serbia) }\end{array}$ & $\begin{array}{l}\text { Zemlinium (Ze- } \\
\text { mun, Serbia) }\end{array}$ & & $\begin{array}{l}\text { Clocoduiza } \\
\text { (Klokotnitsa, } \\
\text { Bulgaria) }\end{array}$ & \\
\hline $\begin{array}{l}\text { Belgradum (Beo- } \\
\text { grad, Serbia) }\end{array}$ & & & $\begin{array}{l}\text { Hormanly (Har- } \\
\text { manli, Bulgaria) }\end{array}$ & \\
\hline \multicolumn{5}{|l|}{$\begin{array}{l}\text { Zmiderovium } \\
\text { (Smederevo, Ser- } \\
\text { bia) }\end{array}$} \\
\hline \multicolumn{5}{|l|}{$\begin{array}{l}\text { Jagodna (Jagodna, } \\
\text { Serbia) }\end{array}$} \\
\hline \multicolumn{5}{|l|}{$\begin{array}{l}\text { Nessus/Nys (Niš, } \\
\text { Serbia) }\end{array}$} \\
\hline \multicolumn{5}{|l|}{$\begin{array}{l}\text { Pyroth/Pyrottus } \\
\text { (Pirot, Serbia) }\end{array}$} \\
\hline \multicolumn{5}{|l|}{$\begin{array}{l}\text { Zophia (Sofia, } \\
\text { Bulgaria) }\end{array}$} \\
\hline $\begin{array}{l}\text { Tatar Pazarcyz } \\
\text { (Pazardzhik, } \\
\text { Bulgaria) }\end{array}$ & & & & \\
\hline
\end{tabular}




\begin{tabular}{|l|l|l|l|l|}
\hline \multicolumn{1}{|c|}{ Oppidum } & Arx & Castellum & Pagus/Vicus & Comitatus \\
\hline $\begin{array}{l}\text { Philipopolis } \\
\text { (Plovdiv, Bulgaria) }\end{array}$ & & & & \\
\hline $\begin{array}{l}\text { Ciermenium } \\
\text { (Chernomen, } \\
\text { Bulgaria) }\end{array}$ & & & & \\
\hline $\begin{array}{l}\text { Hadrianopolis } \\
\text { (Edirne, Turkey) }\end{array}$ & & & & \\
\hline
\end{tabular}

Apart from place names, we can find many names of rivers in the travelogue. In addition to the Danube (Danubius), where the first leg of the journey takes place, the following rivers were also part of the scheduled itinerary: Drauus (the Drava), Sauus (the Sava), Moschius (the Morava), Nessus (the Nišava), Strymon (in Vrančić's text the name Strymon refers to the River Maritsa), ${ }^{30}$ Izcar (the Iskar) and Topolniza (the Topolnitsa). ${ }^{31}$ Vrančić does not stop at only listing the rivers he encounters on the road, but he also tries to provide additional information to the reader, and lists names of some other rivers specific to a particular area he currently finds himself in. In his digressions the following rivers are mentioned: Tibiscus (in Vrančić's travelogue the Tisza) ${ }^{32}$ Chrysius (the Sebes Körös), Toncia (the Tundzha), Nessus (the Mesta), Melanis (the Kara Su), Arzus (the Arda), Athyra (the Kara $\mathrm{Su}$ ), Bathynia (possibly the Sazli Dere), Ztara Richa (the Stara Reka), Iadina (the Luda Yana), Cruzka and Gergoua. ${ }^{33}$

In his travelogue, Vrančić also mentions hills and mountains, and not only those which he passes, but also those in the immediate surroundings of his travel route. Thus, sailing along the Danube, near the place where the Drava flows into the Danube, he talks about a hill which the local population calls Harsanus, ${ }^{34}$ and travelling through the area in Serbia where the town of Sremski Karlovci is located, he describes the mountain of Almus or Frusca (Fruška Gora). After his arrival in Niš, our travel writer takes the opportunity to write about the three major mountain ranges in the area - Scardus (the Šar Mountains),

${ }^{30}$ Vrančić equates the River Struma (ancient name Strymon) with the River Maritsa (ancient name Hebrus). Therefore, in his writings, Struma or Strymon always refers to Maritsa. See the next section for this and other Vrančić's errors when it comes to river names.

${ }^{31}$ The names of rivers are given according to Vrančić's autograph.

32 In his text, Vrančić incorrectly calls Tisza (the ancient name Tisia or Pathissus) Tibiscus, which is the ancient name for the River Tamiš.

${ }^{33}$ The names of the identified rivers the Sebes Körös, the Kara Su and the Sazli Dere have been taken from the translation by D. Novaković in Vrančić, Putovanje iz Budima, 143, note 38. Cruzka and Gergoua are not identified.

${ }^{34}$ D. Novaković sees a great similarity between this name and the name of the mountain and fort of Harsány in the Hungarian part of Baranja, but if this is really the mountain in question, then Vrančić located it incorrectly (according to D. Novaković in Vrančić, Putovanje iz Budima, 121, note 4). 
Orbellus (the north-western part of the Rhodope Mountains together with the mountain of Rila) and Haemus (the Balkan Mountains or Stara planina). Then he mentions the mountain of Vitossa (Vitosha), at the foot of which the city of Sofia is located. ${ }^{35}$

This literary segment is closely related to the next one, which refers to the educational role of a travel writer, since Vrančić's interpretations are mostly connected with the explanation of place names.

\subsection{Educational elements and incorrect interpretations of geographical names}

While Vrančić dutifully records the regions through which the delegation travels, he does not let his books out of his hands, especially Ptolemy's Geography, with which he continually compares those regions. In addition to referring to his travel literature, Vrančić, in accordance with the educational role of a travel writer as dictated by the conventions of travelogues, often offers explanations about the lands through which he travels. As a typical example for this can be mentioned the quote about Vrančić's passage on the Šar Mountains:

“... sumeturque considerationis huius initium a Scardo monte, qui iuxta V. tabulam Europeam Ptolemei iunctus est ab occidente montibus Bebiis, a meridie vero Orbello, ne ulteriores commemorem ab usque ipsis Pireneis, a quibus omnes sumunt originem, qui Cathena mundi appellantur, quod vno ordine ab occasu in ortum provecti, donec Scardum attigerint, inde a Scardo ad meridiem ducti in Pontum supra Mesembriam ciuitatem desinunt." 36

Although Vrančić believed that in his rather frequent interpretations of names of places, rivers and mountains he was informing and educating his readers, it is here that he is frequently mistaken. Below will be discussed some of the geographical mistakes that he made.

After a very accurate description of Belgrade, our narrator goes on to explain the origin of its name where, among other things, he states that the Romans called it Taurunum, but actually this name refers to Zemun, while the antique version of Belgrade, Singidunum, found in Ptolemy's Geography, is not mentioned here. He also erroneously identifies the name Tricornium with Smederevo, arguing that the town has a triangular shape, which largely corresponds to the etymology of

${ }^{35}$ In his travelogue, Vrančić also mentions other oronyms. According to Matković ("Putovanja po balkanskom poluotoku", 38-39), Vasilizza is a well-known Bulgarian name for Ikhtiman Sredna Gora, while Zlauieui is the local name for the Rhodope Mountains ("Putovanja po balkanskom poluotoku", 49). For the oronyms Lukauiza and Rupzca Matković ("Putovanja po balkanskom poluotoku", 25, 46) we could not find confirmation in the literature.

${ }^{36}$ HU-OSZK-2380-fol. Lat., III, f. 104v. 
the name Tricornium. Still, this is not Smederevo, but probably present-day Ritopek, a village on the right bank of the Danube, southeast of Belgrade. ${ }^{37}$

Furthermore, Vrančić assigns Sofia the ancient name of Ulpianum. As a confirmation, he offers the mythological story he heard from the local inhabitants, a story about the founder of the city, the wife of a Greek emperor who allegedly replaced the name Ulpianum with Sofia, the protector of the same name. Vrančić's mistake is evident, as the ancient name of Sofia has been confirmed as Ulpia Serdica, ${ }^{38}$ while the name Ulpianum refers to Gračanica in Kosovo. ${ }^{39}$ In another attempt at presenting an etymological explanation, in the exhaustive description of the city of Plovdiv (Philippopolis) the author once again errs by identifying Plovdiv with the Macedonian city of Philippi (Philippoi). Furthermore, at one point he claims that Teutoburgium is Pécs, Cornacum Karlovci, Acumincum Kamenica, and Rittium Slankamen; however, they are actually Dalj (Teutoburgium), Sotin (Cornacum), Stari Slankamen (Acumincum) and Surduk (Rittium). ${ }^{40}$

Our travel writer also records a number of erroneous river names in his text. Thus for the River Iskar (Vrančić has it as Izcaris, its ancient name being Oescus), he says it is Ptolemy's Ciabrus, making this argument:

"Izcarem autem Ciabrum esse non difficili coniectura assequutus sum. Primum quod iuxta positionem in Ptolomaeo huius fluminis aliud flumen nullum est, deinde quod moderni quoque incolae hunc ipsum amnem et vrbem Zophiam terminum ponunt inter Mysiam superiorem et inferiorem cum Thracia..."

Vrančić was also mistaken when he interpreted that Mariza is an Illyrian version of the name of the Struma River, along with, as he puts it, the common Greek and Roman name Strymon and the Turkish name Mericz. Furthermore, he denies the true classical name of the River Maritsa - Hebrus. The consequence of this mistake is that the name Strymon actually refers to the Maritsa everywhere in his text. He also identifies the River Mesta (Nestus, Nesus) with Tundzha (Tonzus), again referring to Ptolemy's Geography, and Tisza (Tisia) with Tamiš (Tibiscus). ${ }^{42}$

${ }^{37}$ According to Gavro A. Škrivanić, "Jugoslovenske zemlje na Pojtingerovoj karti”, in: Monumenta cartographica Jugoslaviae I, ed. Relja Novaković (Beograd: Istorijski institut, 1974), 15.

38 Škrivanić, "Jugoslovenske zemlje", 45.

39 Škrivanić, "Jugoslovenske zemlje", 16.

${ }^{40}$ Vrančić's incorrect place names and erroneous explanations for them can be found in Matković, "Putovanja po balkanskom poluotoku", passim, and Novaković in Vrančić, Putovanje iz Budima, 125 (note 12), 127 (notes 14 and 15), 135 (note 24), 138 (note 28).

${ }^{41} \mathrm{HU}-\mathrm{OSZK}-422-$ fol. Lat., II, ff.77v-78.

${ }^{42}$ For the mistakes regarding river names see Matković, "Putovanja po balkanskom poluotoku", passim, and Novaković in Vrančić, Putovanje iz Budima, 123 (note 9), 133 


\section{Conclusion}

Even though this travelogue lacks the description of the last leg of the journey (from Hadrianopolis to Constantinopolis) for unknown reasons, Vrančić's account of his diplomatic journey can legitimately be regarded a literary travelogue because it contains all elements characteristic of this literary genre - a narrator, a specified reason for the travel and the person who commissioned it, a specific itinerary, digressions as supplementary thematization, educational elements and narrative and descriptive passages. What makes this travelogue very interesting is that one can feel the author's subjective involvement in many of its descriptive passages. Vrančić does not only provide his readers with factual information about the places he visited; his own emotions of enthusiasm and wonder all the way to fear and shock permeate the entire travelogue. For this reason, we can find out a little bit about him, his feelings and attitudes from his writings as well. Vrančić's active role as the narrator of his travelogue is particularly manifested in his desire to educate his readers about the regions he visited in great detail, which led to his occasional mistakes in his interpretations, which we frequently cannot explain. But, despite those "mistakes" and disinformation that cannot be said to be unthinkable for a traveller in the period of the Renaissance, we can conclude that the travelogue Iter Buda Hadrianopolim is a unique and precious literary work from the period of Croatian humanism.

(note 23), 138 (note 28), 141 (note 31). For incorrect orographic explanations see Matković, "Putovanja po balkanskom poluotoku", passim. 


\section{SOURCES}

Hungary - Országos Széchényi Könyvtár, Budapest - 2380 - fol. Lat., III, ff. 81-112v (HU-OSZK-2380-fol. Lat., III)

Hungary - Országos Széchényi Könyvtár, Budapest - 422 - fol- Lat., II, ff. 77-98v (HU-OSZK-422-fol. Lat., II)

Vrančić, Antun. Putovanje iz Budima u Drinopolje. In: Alberto Fortis, Put po Dalmaciji, edited by Josip Bratulić, translated by Mate Maras and Darko Novaković, 115145. Zagreb: Globus, 1984.

\section{BIBLIOGRAPHY}

Birnbaum, Marianna Daisy. Croatian and Hungarian Latinity in the Sixteenth Century. Zagreb: Most, 1993.

Blažević, Zrinka; Vlašić, Anđelko, eds. Carigradska pisma Antuna Vrančića. Istanbul: Hrvatska akademija znanosti i umjetnosti, 2018.

Duda, Dean. Priča i putovanje. Hrvatski romantičarski putopis kao pripovjedni žanr. Zagreb: Matica hrvatska, 1998.

Duda, Dean. "Putopis: Od pokušaja određenja žanra do Krležina diskurza". Umjetnost riječi XL (1996), br. 2-3: 71-83.

Duda, Dean. "Figure u opisu prostora". In: Tropi i figure, edited by Živa Benčić and Dunja Fališevac, 427-449. Zagreb: Zavod za znanost o književnosti, 1995.

Fortis, Alberto. Viaggio in Dalmazia. Venezia: Presso Alvise Milocco, 1774.

Grässe, Johan G. T.; Benedict, Friedrich; Plechl, Helmut; Plechl, Sophie Charlotte. Orbis Latinus. Lexikon lateinischer geographischer Namen des Mittelalters und der Neuzeit. Braunschweig: Klinkhardt \& Biermann, 1972.

Koller, Jószef. Historia episcopatus Quinqueecclesiensis V. Posonii et Pestini: Sumptibus Joannis Michaelis Landerer, 1782-1784.

Matković, Petar. "Putovanja po balkanskom poluotoku XVI. vieka. Putovanje A. Vrančića g. 1553. u Carigrad". Rad JAZU 71 (1884), 1-60.

Novaković, Darko; Vratović, Vladimir. S visina sve. Antun Vrančić. Zagreb: Globus, 1979.

Novaković, Darko. Sentimentalni odgoj. Antun i Faust Vrančić (Šibenik: Gradska knjižnica "Juraj Šižgorić", 1995.

Sorić, Diana. "Klasifikacija pisama Antuna Vrančića". Colloquia Maruliana XVIII (2009), 83-117.

Sorić, Diana. "Obiteljska korespondencija Antuna Vrančića: kritičko izdanje rukopisa i jezičnostilske osobitosti”. Doktorska disertacija, Sveučilište u Zadru, 2012.

Sorić, Diana. "Obiteljski korespondenti Antuna Vrančića (1504.-1573.): Biografski podaci i lokacija rukopisne građe". Povijesni prilozi 47 (2014), 35-61.

Sorić, Diana. "Pitanje datuma rođenja hrvatskog humanista i ugarskog primasa Antuna Vrančića (1504.-1573.)”. Croatica Christiana periodica 39 (2015), br. 75: 37-48.

Szalay, László. Monumenta Hungariae Historica II/2. Pest: Eggenberger, 1857.

Škrivanić, Gavro A. "Jugoslovenske zemlje na Pojtingerovoj karti”. In: Monumenta cartographica Jugoslaviae I, edited by Relja Novaković, 31-58. Beograd: Istorijski institut, 1974.

Vrančić, Antun. Historiografski fragmenti. Edited by Šime Demo and Castilia ManeaGrgin. Šibenik: Gradska knjižnica “Juraj Šižgorić”, 2014.

Tvrtković, Tamara. "Marko Marulić u djelu Ivana Tomka Mrnavića”. Colloquia Maruliana XVI (2007), 293-306. 